\title{
The poetry of Bartlomiej Majzel: a psychoanalytic approach
}

\author{
Marcin Jurzysta \\ jurzysta@umk.pl
}

\begin{abstract}
Bartłomiej Majzel is one of the most interesting young polish authors. His first poetic book is robaczywość [worminess] published in 1997. As regards interpretation, many motifs which recur in the volume, suggest a psychoanalytic approach. This approach reveals a dark world of sub-consciousness and transcription of struggling against oneself, reporting the consequences of this tragic party called literature.
\end{abstract}

Key words: new polish poetry, psychoanalysis, sub-consciousness, mental illness.

Bartłomiej Majzel is an author of four poetic books, the first of which is robaczywośc [worminess], published in 1997. The author of robaczywość lives in Katowice. He is not only a poet but also a columnist and the editor of the no longer existant magazine "Na Dziko". According to the anthology Tekstylia, „his debut was in 1992 in »Kurier Zachodni«. He was included in the list of fourteen poets that M. Stala considered the most interesting creators of new poetry. As a member of the poetic group »Na Dziko«, Majzel was associated with the socalled Silesian school of life poetry. However, in contrast to the majority of its members (including M. Melecki, the group leader), who focused on breaking the barbarian aesthetics and moving in the direction of the postmodern poem, Majzel abandoned the poetics of sensual description for the sake of thickening metaphors as well as modernist or even romantic reminiscences" (Marecki, Stokfiszewski, Witkowski 2002, p. 417-418) ${ }^{41}$.

One of the most significant motifs of B. Majzel's debut book is "dual personality" of the character. This motif is simultaneously the bond that links other elements. The character of B. Majzel's book is without doubt a dynamic figure. The reader does not at the beginning

\footnotetext{
${ }^{41}$ All quoted fragments were translated by myself except original fragments from The Pervert's Guide to Cinema.
} 
obtain access to the character constructed in this, and not any other, way. Each poem and each of the three parts of the book are stages that demonstrate the shaping and changing of the subject's features in this story. The aforementioned process thus concentrates on the character's evolution, determined by the parts of the triptych. Everything begins from the first poem, namely, autoprzeprawa [auto-crossing] :

“in 43 among explosions my grandmother gave birth to my papa in the cellar

$[\ldots]$

now 53 years after that night

in the cellar my papa keeps potatoes

which spread rhizomes in the warmth.

I havent't earned my own cellar yet.

I've found very fast

other aching places.

where misshapen oddments come together

this what goes on" (Majzel 1997, p. 6).

As regards interpretation, the motif of the cellar, which recurs in the volume, seems most significant. When moved beyond the direct meaning and analyzed in the context of the character's structure, the motif imposes a psychoanalytic aspect. If one is to imagine a house consisting of the levels of cellar, floor and attic, such a house arrangement can symbolize the Freudian division into the Id, ego and super-ego. The cellar will then be the metaphor of the darkest part of the human psyche, the sphere of the unconscious (or rather subconscious) drives or - in general - the reservoir of all that was closed in it, relegated and driven out of the consciousness. It is here that "misshapen oddments come together // this what goes on". This content is not easy, so the cellar is one of the "sore places". The title "auto-crossing" will be then the crossing through oneself: through one's psyche and descent from the real level of consciousness into the dark cellar or some other similar place. This penetration into one's self runs the risk of upsetting the balance between the elements of the psychic structure; it poses the threat of bringing someone else out of the consciousness (the second "bartek majzel" that recurs in robaczywość), someone who takes control over the character and whispers in the character's ear, and will make the latter translate this whispering into poems. "Explaining and translating are significant words; they are even essential in order to understand the world 
hollowed out by the 'worm of the alleged schizophrenia'. It concerns the real figure of Bartłomiej Majzel and the imposition of the phantasmagoric figure of »bartek majzel« upon the former. In this sense, all lyric poetry is schizophrenic (it brings out the other). In this case, there are conditions that have been deliberately created for its special development. Next to the subject there is some trembling »bartek majzel«, who translates, corrects, explains and, in his own way, puts the screws on his visions. Robaczywość read form this slightly pathological perspective emerges as an epic of autism and the immersion into something very personal and »different «: sticking in the cellar of twisted personality and its unsatisfied sexual drives that break through the spider-, worm- and cockroach-like visions. I draw my attention to this particular celebration: the surrealistic ritual of carrying something that proclaims to all and sundry that in fact it replaces something, and in this there is a method. I do not know whether the method applies to the act of hiding or exposing. If the first gesture designates the message: I give you this world instead of the other; the second means that the more I am burdened, the more appropriately I am covered with inexplicable pictures and neurotic prattle" (Maliszewski 2001, p. 243-244).

Still, in the context of psychoanalysis we can interpret the fact that "these poems are translations". It is enough to point to the Freudian theses concerning the dream-work. "Dream-work is a dynamic structure firstly made of the hidden thought (Traumgedanke): the material to be handled and the unconscious core. The dream thought is the original source text that is subject to processing by the dream-work. The dream-work transforms the hidden (latent) into the manifest. Its main function is to cover up the traces leading to the right understanding of the masked intentions. It resembles translation (Übersetzung), which is simultaneously deformation or distortion (Einstellung). The dream-work acts in a comparable manner to the creation of a literary text: $\gg$ the threads of associations do not lead directly from the thought to the content of the dream-work: they are often crossed and tangled on their way«. This intersection of the thoughts has a tropological (symbolic) character. The dreamwork tropology is the system of deformations and distortions of the content of the hidden dream. They comprise condensation or density, the manner in which metaphor works (Verdichtung), and displacement (Verschiebung), the manner in which metonymy and representability (Darstellbarkeit) work. Words are translated into pictures, which lead to secondary revision (sekundäre Bearbeitung): one vision is transformed into another one. The dream-work, which leads to the distortion of the content of the hidden thought, is constantly subject to censorship. Dream analysis concerns processing and handling of what is deformed 
and distorted; in other words, its aim is to reach the latent content of the dream-work through the appropriate interpretation of the manifest content. It is the effect of the dream-work and the transcription of the dream thought which is characterized by incomprehension and lack of clarity” (Burzyńska, Markowski 2006, p. 55-56).

We therefore deal with the character who is immersed into his own sub-consciousness (he descends into the "sore place"). He reaches there his other "I", which reveals everything hidden in the unconsciousness to him. The lyric "bartek majzel" makes translations that distort the original meaning. The translations hide the meaning and present it in a more accessible form; they also protect it from a too excessive exposition of one's self and one's inner life. This method is not the exhibition of oneself but rather an attempt to curb oneself. The poem hides the content which is both latent and distorted: these are the aforementioned distortions that take place within the psychic apparatus as well as the changes resulting from formal solutions. It is the adaptation of the already distorted thought for the requirements of lyric poetry. In the poem entitled $b . m$. there is a description of what happens to the character, who has transgressed the border of unconsciousness:

"[...] wind is

moving inside me and throws everything around.

my every blood vessel dangles.

every tiny vein. muscle of fear" (Majzel 1997, p. 9).

Fear becomes a dominating feeling, which is so intensified that it leads to physical symptoms (fear becomes an inseparable element of the physiology). It is the fear of what has so far been hidden and of the force by which the character is influenced; it is the fear "of the wind that moves within the character". Wind is an element: it is the force symbolizing "the air in its active and violent aspect. On account of its similarity to the breath of creation, it is considered the first element. Jung stresses that similar to Hebrew, in Arabic the word »ruth « means both »breath « and »spirit«. In its most intensive form, wind gives birth to a hurricane, the synthesis and the combination of four elements, ascribed with the force of fertilization and revitalization" (Cirlot 2006, p. 446).

The vision of internal tension and the struggle against one's own unconsciousness also appears in the following, adjacent to b.m., poem entitled wołacze wołaja [vocatives call] :

"poems bore - unimaginable -

- in the throat shavings poured out - such touches 
nobody expected -

- weighty dragon-flies adherent from bottom of light -

- acrid liquid floods

there will be nothing

nothing will overflow me

howling howls - it can't be differently -

tear lies" (Majzel 1997, p. 10).

It is the language that expresses the other ' $\mathrm{I}$ ': the language becomes the way out of the level of unconsciousness. The process described by B. Majzel has a transgressive character: it concerns crossing the borders created by one's own psyche and opening the "door of perception", which results in the liberation of the other nature and, simultaneously, the discovery of the reserves of suffering and pain:

“[...]

what about those other dins? other ashes?

all this became after us.

speeding. through larynx. through

tunnels I roam.

since somehow I managed to go out

I will feel precipice" (Majzel 1997, p. 18).

In the passage quoted, there is an image hiding two perspectives: the one of degeneration, destruction and catastrophe; and the other of liberation and breaking from the limiting bonds. On the one hand, the psychic structure of the character breaks apart; on the other, based on these ruins there appears the other character: "speeding" and rushing "through the larynx", as well as marking its presence in the language, words and poems. The final poem in the first part of the book concludes the first stage of transformation to which "bartek majzel" submits himself.

"[...]

I assembled my strength on this what's beyond me.

I pulled the flames of head. earthquakes.

winds of sweaters. flannel shirts.

everything has always rushed. it has rushed to alive. 
and despite this one should to try again

to unscrew. to speed up. to burn beds behind

and to disregard nights like excavators

which cut to the quick so much

[...]" (Majzel 1997, p. 20).

The first stanza carries the premonition of degeneration: it is a dance on the verge, treading on the border of one's consciousness and one's identity. The second stanza is a movement one step further: transgressing the border and disrespecting the warnings in the form of nightmares, which at night were bringing the poor substitute or rather the unclear harbinger of what awaited over the other side of oneself. Ślimaczywość matowa [Matte snailness] brings yet another image that can relate to the process described:

"[...]

I don't know how this happens, that we can't

to each other. that we don't speak out.

that we turn on side.

but we write more and more better poems.

we paint strained canvases.

we carve in air" (Majzel 1997, s. 27).

Lack of articulation of the hidden desires, dreams and, finally, instincts bears their accumulation, their relegation into the reservoir of the unconsciousness and eventually their sublimation, the movement into the language of the poem. What the character could not realize and say openly is expressed in the poem and its specific aesthetic code that the character uses.

One cannot be surprised by the fact that in robaczywośc there is a saliently articulated motif of paranoia and madness, which can be treated as the price for liberating the unconscious. In the poem 41,4 there appears one of the images of mental illness:

"[...]

adela has lots of worms

in her tights. on addition

she complains on night shouts

coming from the side of katowice,

despite hallucinations and slow loss of consciousness

she protests when doctor give her thermometer. 
one should measure temperature only between man and woman. she whisper" (Majzel 1997, p. 15).

The appearing motif of "the temperature of feelings" can be associated with E. TkaczyszynDycki. In reference to schizophrenia this "fever of love" can connote the first phase of illness: the wave of seizure. "One feature of the first phase is a more or less violent movement from the so-called normal world into schizophrenic one. The mentally ill person becomes possessed by the new way of viewing himself and his surrounding reality. If the possession is violent, the mentally ill person suddenly finds himself in another world: the world of vision, ecstasies, nightmares, and the altered proportions and colors. Such a person himself or herself becomes someone completely different: he or she discovers their authentic self and sheds the old mask that hindered and limited him or her. He or she acquires an authentic new self: heroic, in opposition to the whole world, with the mission to carry out or with a feeling to liberate from the old self. Such a person also experiences a state of chaos, emptiness, their own evil and the hatred for themselves and the whole world" (Kępiński 1981, p. 46-47). The aforementioned extreme "amplitude of feelings" is present in Majzel's poem moje. Przechodzenia [mycrossing] :

"[...]

but it just has to be that way -

word then scream always one after another never at once.

there has to be revolt if reconciliation could come

and there has to be anger if love could appear" (Majzel 1997, p. 46).

The "crossing" takes place between the extreme emotions; it is the only state in which the character can function properly, and knows that he is able to feel and, in particular, to feel true.

When interpreting the motif of unconsciousness, the peculiar "auto-psychoanalysis" presented above, one should mention some other points in Majzel's book in which it is signaled. In the poem stukot hi hi [clatter hi hi], the passage featuring the symbolism of wind appears:

"[...]

Under-age girl hides herself from wind behind shop.

struggling with dress which still

breaks off her hips

[...]" (Majzel 1997, p. 12). 
It is not the first time that wind has appeared as the force, which here can be related to libidinal drives. "The Under-age girl” recognizes the symptoms of Eros's action: the drive for love requires realization and fulfillment. An interesting piece of literature that brings intriguing observations opening the psychoanalytic context is Ruch Chorzów - Legia Warszawa 0-2 (0-1 Mandziejewicz, 0-2 Michalski):

"fuck referee you fucking Jew

make him show his dick maybe his's circumcised

fuck ruch

torture legia

clowns clowns

finish him finish him off

I bought myself piece of sausage costing 3 zlote

though I still had inside me smell of soup

cooked by wojtek's mom. little boy sat near

purring something. his first eye looked at

pitch the second eye winked like a warm.

it seemed he wanted to call:

kiss referee

you bird of sky

let him draw out his hand

pet ruch

love legia

angels angels

heal him heal him" (Majzel 1997, p. 22).

After the first reading, this text seems completely detached from the poetics of the author of robaczywość. The directness of the phrases from the first stanza and the colloquialism moved into obscenity, emphasized with the use of quotation marks, are rather features of the early "bruLion's" poetics. However, when one applies the psychoanalytic approach, which has already been used, for interpretation, it is this perspective that precipitates (the initially indiscernible) semantic sources. The first stanza is then the voice of the Id: the articulation of 
the subconscious force and destructive drives that are expressed in anger and aggression. Then, there appears the following passage:

"I bought myself piece of sausage costing 3 złote

though I still had inside me smell of soup cooked by wojtek's mom [...]" (Majzel 1997, p. 22).

In this passage, there is an expression, even if in a more subtle way, of the unconscious ' $I$ '. The constant consumption, continuous generation and satisfaction of drives, and infinite lack of satiability are among the features of Id. Finally, there appears the last stanza, preceded by the appearance of the mysterious "under-age" boy. In the light of such an interpretation, he will reflect the super-ego, which is the reversal and denial of the hedonistic Id and its nature. The whole poem thus becomes the depiction of two contrary forces that co-condition the functioning of the ego. On the one hand, it is the pleasure principle, which demands satisfaction; on the other, there are norms, bans, rules and conscience. The struggle against the interior drives, oscillating between total satisfaction and total withdrawal (in other words asceticism) is visible in the passage from ślimaczywość szklana [Glass snailness] :

"on the edge of the week I have my hair cut.

head changed its shape

like sceptre and hyacinth or even distressing proclaim.

night order of things was scattered again.

after-effect of wonders reversed

hair fell down first and really then

one could hear the scissors's cuts.

[...]" (Majzel 1997, p. 39).

In order to discern the image mentioned, one has to become aware of the symbolic dimension of hair. "In its more general sense, hair is a sign of energy. Its symbolism is related to the symbolism of level; that is, luxuriant hair that adorns one's head emblematizes supernatural forces and thick body hair designates the proliferation of a lower element [...]. Hair corresponds to the element of fire, which symbolizes the principle of primordial force [...]. In Libro d'oro del sogno Phaldor states that hair represents the human spiritual goodness. Beautiful and thick hair means a spiritual development in the case of both man and woman. Hair loss is equated with defeat and poverty. Nevertheless, voluntary sacrifice is to a certain extent the opposite of the loss caused by something external. This is why Zimmer stresses that the one who renounces the forces of fertility or rebels against the rules of begetting and 
reproducing new lives in order to begin one's way of absolute asceticism, usually has to cut one's hair [...]. The Sumers had their hair, wig and beard removed as the protection against evil spirits (that were like smoke)" (Cirlot 2006, p. 455).

All that is unconscious, as has already been indicated, is expressed in the language, words and voice (the motif of which is important in B. Majzel's works) in the context of a dynamic development of the character's nature and the process to which he is submitted. In order to discern the specific traits and attributes of the voice in the poems of this poet from Katowice, I will take the liberty of a distant digression and interpret the voice as an element and as a mysterious force. In part of the film The Pervert's Guide to Cinema S. Žižek touches upon the problem of voice in its psychoanalytic dimension: "the voice is a palpable part of the body. It emerges from some place in the body. When we talk to another person, there is always some minimal ventriloquist's effect, as if some strange force possessed us. At the beginning of The Exorcist (1973), the character presented in the film is a pretty girl. How did she become a monster? It was because of possession. But who possessed her? It was the voice that did it. It was the voice in its obscene dimension. The question arises: how to get rid of this strange other. It appears as if we were waiting for the famous scene from Ridley Scott's Alien film (1979) to repeat itself; as if we were waiting for the monstrous, strange, and evil small animal about to spring out. We can discern here the lack of balance: the gap between our psychic energy that Freud called libido, our infinite energy that transgresses life and death, and the poor, finite and fatal reality of our bodies. It does not only concern the pathology of being possessed by spirits. We ourselves are strangers that dominate our bodies. Our ego, a psychic factor, is an alien force that deforms and controls the body. The first significant film about this traumatic dimension of voice was shot in the 1930s in Germany. It was The Testament of Dr. Mabuse (1933) by Fritz Lang. It is not until towards the end of the film that we see Dr. Mabuse. He is only a voice. Charlie Chaplin was the first person to become aware of such a traumatic dimension of voice: not as an elevated and ethereal means of expressing the depth of human subjectivity but as an alien intruder. Chaplin was the first person to notice this in The Great Dictator (1940). The problem in this film is about how to get rid of the terrifying dimension of voice; or, if it is not possible to eradicate it, how to adapt it into some means of expressing humanity, love, etc. The German police think that the poor vagrant is Hitler. He has to speak in front of a large gathering. He delivers a great speech concerning the need for love and understanding among people. But there is a catch: as was the case with Hitler, the people applaud him. Another example comes from a short scene in 
Mulholland Drive (2001) by David Lynch. A woman sings into the microphone. Suddenly, she faints for no apparent reason. Surprisingly, her singing continues. The matter is explained very quickly: it was a case of playback. But for a few seconds we feel confused: we are face to face with the terrible dimension of autonomic part, which is voice" (Fiennes 2006).

The voice as an element, voice that is independent and detached from its subject, and the voice against which we need to struggle also appears in robaczywość:

"things we were saying stopped belonging to us

since cut off hair had fallen on the grass and really then

one could hear those cuts in the dark. faithfully repeated” (Majzel 1997, p. 39).

Language and voice are potential sources of suffering: “[...] tongue will hurt yet” (Majzel 1997, p. 11). In the case of B. Majzel, similar to the films described above, voice becomes independent in a specific way. It endeavors to gain autonomy in relation to the character, who loses control of the words pronounced: “sentence which I'm writing is turning between teeth//like it wanted to fall out" (Majzel 1997, p. 15). Language is an element of unconsciousness:

"[...]

storm on the throat. if in this downpour was

one silence at least. if one silence

was in whole water

[...]" (Majzel 1997, p. 20).

The character attempts to struggle with his "own" voice and, at the same time, the content of sub-consciousness:

"tangerines in the throat. blood of juice under the tongue

gathers. word detained on the teeth stammers

now it's spat out like the remainders of sinewy meat.

[...]" (Majzel 1997, p. 26),

“[...] whatever doesn't enter the closeness//before dusk. whatever to push away heard voices" (Majzel 1997, p. 44).

Simultaneously, the subject of these poems knows that the voice, representing the other nature hidden in the recesses of the psyche, demands its release. The subject also knows that silence is terrible and that seeking to avoid the inevitable: "I fear the lack of voice" (Majzel 1997, p. 43), "the largest risk is related with non telling//or telling to yourself. words bites each other like the asbestos of air inside"(Majzel 1997, p. 54). 
The title robaczywość is a dominating element of space in Majzel's debut collection of works. The category of worminess appears even in autoprzeprawa. When there appears the image of the cellar, there also appears the aforementioned category: "I don't know if there were worms//I don't know if it was warm or too cold" (Majzel 1997, p. 6). "Worms" are then inseparably linked with the sub-conscious and with "the cellar of the psychic apparatus" . They initiate the process of bringing to light the hidden contents, "spreading rhizomes like potatoes" . By the same token, they are related to the degeneration of the structure, which so far has been unanimous. The reference of this interesting category to the question of psychic processes, and to what can be described as the degeneration of the psychic structure, can be found in the poem 41,4 :

"[...]

adela has lots of worms

in her tights. on addition

she complains on night shouts

[...]" (Majzel 1997, p. 15).

It is an image of paranoia, which is the state of some specific liberation of the mind from one way of functioning defined by norms. Simultaneously, "the worms in the tights" are one of the symptoms: these are one of the images implied by madness. Worminess is also manifested in time: it is rooted in time, or even determines the rhythm of its passing:

"[...]

and years cast through fields

like cockchafers.

where? maybe to ceiling?

or maybe they shrank as red

apple which I left in wardrobe?

[...]" (Majzel 1997, p. 7).

In the passage above there appears a figure of an apple as an example of a worm-eaten fruit. "As an almost spherical form, the apple is associated with wholeness. It is a symbol of earthy desires and their unbridling. That is why the ban on eating apples was expressed by the highest voice, objecting to the adoration of material desires. Even Nietzsche knew that Intellect and desire for cognition are the sphere between earthy desires and pure as well as genuine spirituality" (Cirlot 2006, p. 166). If the apple symbolizes a complete structure, the 
presence of the worm signals degeneration of this structure. The earthy desires included in the semantics of this symbol can be referred to the sub-conscious and primordial drives, which, on account of the worm, are extracted from the psychic structure. Again, we deal with the indication of psychic degeneration in order to release what so far has been concealed.

The essence of this category is emphasized with the quantity of insects: cockchafers, dragonflies and ants. The spider seems to be the most significant:

"[...] through window

spider of hand pushes. blindly catching.

anything. tightened. empty after opening” (Majzel 1997, p. 14),

"I killed a spider. is it bad that I want to live?// because somehow I'm not able to with it" (Majzel 1997, p 25),

"let spiders enter the sleeping-bags

after which no trace will stay.

except next change of place. that is lodging

in another valley. on another side.

and in the morning. with the same spider which was sneaking

we exchange friendly signs already. - hallo. hallo" (Majzel 1997, p 43),

"on the grass like in the the city I was surrounded by spiders.

behind tree's pieces. from stones. even from the light

they spring out like pimples. which there isn't way to scratch

because they hide in the shadow" (Majzel 1997, p 55).

On the one hand, B. Majzel's spider is an intruder, something that the character is afraid of and would like to get rid of. On the other, one can notice an attempt to identify with the spider (the human hand is presented with the figure of the spider). The character expresses his wish "that the spiders should enter the sleeping bags"; he even exchanges friendly signs with the insect. "As regards the spider, there are three symbolic senses that overlap, are superimposed upon one another, or are separated, depending on the situation. One of them is placed in a dominant position. These symbolic senses are the creative ability of the spider weaving its web, its aggressiveness and the sense related to the spider's web itself: a spiral having its centre. The spider in its web is a symbol of the centre of the world. In this sense, in Indies it is regarded as Maya, timelessly weaving the veil of illusion. The destructive passion of the insect additionally stresses this symbolism of the world of phenomena. It is the reason for 
which Schneider holds that spiders, constantly destroying and constructing, symbolize the unbreakable inversion keeping the life of the cosmos in balance. Thus, the symbolism of the spider is rooted in the human life. It signifies the continuous sacrifice by means of which people constantly change throughout their life. Even after death people actually unravel their old life for the sake of weaving new one. The spider is considered a lunar monster, as the Moon (because of its passive character related to the reflection of light and its phases: affirmative and negative, waxing and waning) corresponds to the phenomenal sphere (manifested in the sphere of psychic imagination)" (Cirlot 2006, p. 299-300). It is this dual nature of the spider symbolism as destructive (threatening) and creative that can be referred to B. Majzel's poems. The spider is here inseparably connected with existence; it is in the figure of the spider that the unconscious is expressed: it hides both the life and death drives. Both are necessary in order to keep the psychic balance. Simultaneously, it is through the appearance of the figure of the spider that the poet signals the extraction of our dark aspects of the human psyche. The drives that are made conscious demand fulfillment and encircle the character. They bring his anxiety to light, which in fact is the fear of himself and his second nature. R. Kobierski states that "being a worm can refer to the state of reaching to the sense. The layers of the earth correspond to the curtains in search of the truth. For some people, it turns out to be fun; for others, it is a matter of life and death. Besides, we will not speak of asceticism and sacrifice: worminess may be connected with the sub-consciousness, and the consciousness of futility and otherness accepted by the subject [...] It results in the assimilation of human and insect features. Worms become attached to people: they keep company during human movements, travels, and the period after death. It is a process of gradual metamorphosis" (Kobierski 1998, p. 150-151).

The factor that is helpful while "emboldening imagination" and, at the same time, opens rich resources of psychoanalytic implications is of course the dream:

"Spaniards tell

about sleeping womans

that they died

and after a while we die all.

somewhere durning breaks in work. during

fast love. in few seconds.

we die in the run. after erection. after vodka. 


\section{$[\ldots]$}

Spaniards tell

that dreams are worminess

emerging at night

[...]" (Majzel 1997, p 36).

We have to deal with the topos of dream as a state similar to death. It is yet another border that Majzel's character seeks to transgress. There is even a connection between the dream and the category of worminess. "Dreams are worminess emerging at night" . Dreams are a gateway to the sub-conscious latent content.

The psychoanalytic perspective visible in Bartłomiej Majzel's book is not necessarily evidence that the poetry of this author from Katowice has a therapeutic character. Bartlomiej Majzel states that "literature is absolutely not a therapy at all. I am always surprised when I hear of literature as a therapy, since I then imagine such authors as Wojaczek, Babiński and others, who sought to apply such a therapy and which turned out to be a tragedy for them. I think that it is just the other way round: literature is a space. When people encounter it, they very often need some therapy. And, of course, I do not want to launch into a pompous or dramatic speech here, but, as Gombrowicz said, literature is a tragic party. ... I think that, when speaking of therapy, we mean people who need peace and quiet, feeling of security, which is of course justifiable and which I understand. However, at this point literature is becoming a tool that should fulfill its psychological obligation. From my perspective, literature is a movement: it is anxiety, tension and the act of balancing on the edge, which excludes any secure elements" (Jurzysta 2008, p. 229-232). In this light, robaczywość is rather a transcription of struggling against oneself, reporting the consequences of this tragic party called literature.

\section{Sources:}

Majzel B. (1997), Robaczywość, Instytut Wydawniczy Świadectwo, Bydgoszcz.

\section{Bibliography:}

Burzyńska A., Markowski M.P. (2006), Teorie literatury XX wieku, Znak, Kraków.

Cirlot J.E. (2006), Słownik symboli, Znak, Kraków. 
Jurzysta M. (2008), Literatura - sztuka czy terapia?, „Kresy”, 3.

Kępiński A. (1981), Schizofrenia, Państwowy Zakład Wydawnictw Lekarskich, Warszawa.

Kobierski R. (1998), Od zawsze gnało do żywego, „Studium”,10.

Maliszewski K. (2001), Zwierze na J. Szkice o wierszach i ludziach, Wydawnictwo Dolnośląskie, Wrocław.

Marecki P., Stokfiszewski I., Witkowskiego M. (eds.) (2002), Tekstylia. O „rocznikach siedemdziesiątych”, Korporacja Ha!art., Kraków.

\section{Filmography:}

Fiennes S. (2006) The Pervert's Guide to Cinema. 